\title{
Earthquake Capacity Assessment Based on Geospatial Model At North Lombok, West Nusa Tenggara
}

\author{
I Gusti Ayu Kusdiah Gemeliarini ${ }^{1 *}$, Muhammad Helmi ${ }^{2,2}$ \\ ${ }^{1}$ Master of Environmental Science,School of Postgraduate Studies, Diponegoro University, Semarang - Indonesia \\ ${ }^{2}$ Departemen of Oceanography, Faculty of Marine Science and Fisheries, Diponegoro, Semarang - Indonesia
}

\begin{abstract}
Environmental management related to seismic activities should be given attention, especially in Indonesia. One of the areas in Indonesia that has an active volcano is the Lombok island, namely Rinjani Mount. According to the center of Volcanology and Disaster Mitigation Bandung, Rinjani Mount still wary status. Losses incurred from a disaster caused by the low human capacity in the region is. Thus it is necessary to know which areas have high, medium and low capacity. So that the community capacity can be optimized, especially in areas with low capacity of the community. The method of this research is to determine the capacity indicator that is used in determining the capacity level of society to earthquake. Create a thematic map for each indicator, then overlay for each indicator that has been given weight according to the level of influence.
\end{abstract}

Keywords: Earthquake; Losses; Community Capacity; Overlay; Arcgis

\section{Introduction}

The position of Indonesian territory located in the meeting of three major tectonic plates in the world, the Eurasian Plate, the Indo-Australian Plate, and the Pacific Plate, make this country one of the countries with high seismic activity level.In addition, Indonesia is on the "Ring of fire" or better known as the Pacific Ring of Fire which is an area that often experienced an earthquake due to volcanic eruptions. So that environmental management associated with seismic activity needs to be considered.

In Indonesia recorded to have 130 volcanoes, 17 of them are still active. One of the areas in Indonesia that has an active volcano is Lombok island, namely Rinjani Mount.Mount Rinjani is one of the volcanoes that are still active and potentially cause vibration and earthquakes, especially volcanic earthquakes [1] Center for Volcanology and Disaster Mitigation Bandung states Rinjani Mount still a wary status.

Total incidenceof the earthquake in Lombok and its surroundings from 1900 to 2014 was 2081 incidents, [2] the quake is a shallow earthquake (a depth of $<70 \mathrm{~km}$ ) that has the potential to cause disaster.

Based on the geological condition of Lombok Island has a high potential for disaster. Lombok island has a loose soil condition, thick, has aquifer, geological condition of muscular structure and fault, and in the northern part of the island is a volcano complex that has a sidemen rock is not compact and easily loose.[3]Based on the geographical location of North Lombok is located at the northern foot of Mount Rinjani. This condition has the potential of earthquake disaster.
Losses incurred from a disaster caused by the low human capacity in the region is. The capacity in question is the resources, means and power that people have to maintain, and prepare themselves, prevent, cope, mitigate and quickly recover from the impact of disasters.

Thus it is necessary capacity-level mapping to know which areas have high, medium and low capacity. So that the community capacity can be optimized, especially in areas with low capacity of the community.

\section{Methodology}

The administrative research is located in Lombok Island, West Nusa Tenggara, precisely at North Lombok.

The data in this study consists of primary data obtained from direct observation activities and the distribution of questionnaires in the field conducted by the author. Questionnaires distributed are 100 questionnaires. The distribution of questionnaire data can be seen in figure 2.1. Secondary data in the form of geological data obtained from Research Center and Geology Development. Map of spatial and regional planning. And topographic map. 


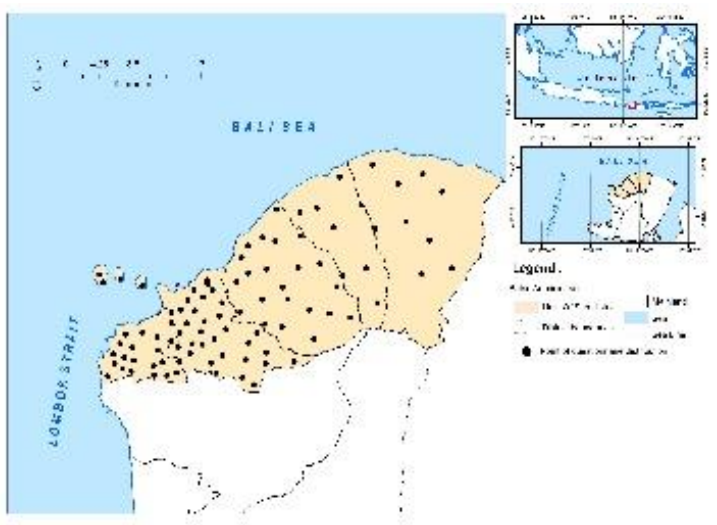

Fig. 2.1. Study Area

The data processing of community capacity level parameters is done by using GIS by giving value and weighting done on each parameter according to the level of influence to the level of community capacity in the research area. Values and weighting can be seen in table 2.1 .

The next step is to convert each parameter into a raster form. This is done because raster data has a simple data structure and is easily manipulated using simple math functions.

Capacity $=(0.03 \times S C)+(0.03 \times P C)+(0.04 \times I C)$

Where :

$\mathrm{SC}=$ Social Capacity

$\mathrm{PC}=$ Physical Capacity

$\mathrm{IC}=$ Intituitional Capacity

Table 2.1 The parameters ofcapacity

\begin{tabular}{|c|c|c|c|c|}
\hline Parameter & Class & Value & Weight & Score \\
\hline \multirow{3}{*}{$\begin{array}{c}\text { Social } \\
\text { Capacity }\end{array}$} & $<33$ & 1 & \multirow[b]{3}{*}{0.03} & 0.03 \\
\hline & $33-66$ & 3 & & 0.06 \\
\hline & $>67$ & 5 & & 0.15 \\
\hline \multirow[b]{3}{*}{$\begin{array}{l}\text { Physical } \\
\text { Capasity }\end{array}$} & $\begin{array}{l}\text { None of the three } \\
\text { indicators }\end{array}$ & 1 & & 0.03 \\
\hline & $\begin{array}{l}\text { There is only one } \\
\text { of the indicators }\end{array}$ & 3 & & 0.06 \\
\hline & $\begin{array}{l}\text { There are disaster } \\
\text { safety instructions, } \\
\text { disaster } \\
\text { simulations, } \\
\text { disaster mitigation } \\
\text { facilities / efforts }\end{array}$ & 5 & 0.03 & 0.15 \\
\hline \multirow{3}{*}{$\begin{array}{c}\text { Institutional } \\
\text { Capasity }\end{array}$} & $\begin{array}{l}\text { There are no local } \\
\text { disaster agencies } \\
\text { and village } \\
\text { disaster risk } \\
\text { reduction forums }\end{array}$ & 1 & \multirow{3}{*}{0.04} & 0.04 \\
\hline & $\begin{array}{l}\text { There is only one } \\
\text { village risk } \\
\text { reduction forum } \\
\text { institution }\end{array}$ & 3 & & 0.12 \\
\hline & $\begin{array}{l}\text { There is a BPBD } \\
\& \text { village disaster } \\
\text { risk reduction } \\
\text { forum }\end{array}$ & 5 & & 0.2 \\
\hline
\end{tabular}

\section{Results and Disccussion}

\subsection{Social Capacity}

Social capacity is a parameter related to understanding of society againstearthquake disasters. This condition is very determine the level of quality an area to face a earthquake disaster. If the quality level of social capacity is high so that the communities can decrease the impact of disasters.

Zoning area with the level of understanding of the community made by dividing 2 classes, that is areas with low levels of understanding (do not understand) and areas that have high levels of understanding (understand). The data used for the preparation of community understanding maps were obtained from questionnaires and interviews conducted directly in the research area.

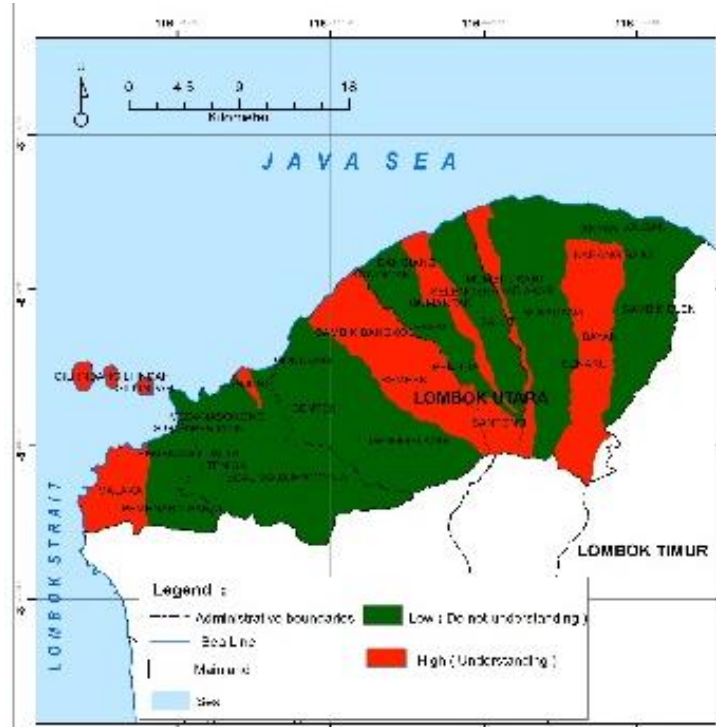

Fig. 3.1 Social Capacity Map

According to the social capacity map, the people who know about the earthquake are reside in malaka village, gili indah, tanjung, rempek, sambik bangkol, santong, gumantar, mumbul sari, senaru, karang bajo, and bayan. People who do not understand are reside in pemenang barat village, pemenang timur, teniga, sigar penjalin, medana, sokong, tegal maja, jenggala, bentek, gondang, genggalang, kayangan, dangiang, sesait, pendua, akar-akar, sukadana, anyar loloan, and sambik elen.

People who do not understand about the disaster are $69.5 \%$ from the area of north lombok district, and the understand one are $30.5 \%$ from the area of north lombok district.

\subsection{Physical Capacity}

Physical capacity is a parameter related to the availability of natural rescue. The availability of rescue tools includes evacuation routes, disaster prone areas, disaster simulations, and disaster mitigation efforts in each village in North Lombok District. 
Zoning areas with the level of availability of rescue tools made by dividing 3 classes, if There are disaster safety instructions, disaster simulations, disaster mitigation facilities / efforts given a score 5, if There is only one of the indicators given a score 3 , and if None of the three indicators given a score 1 .

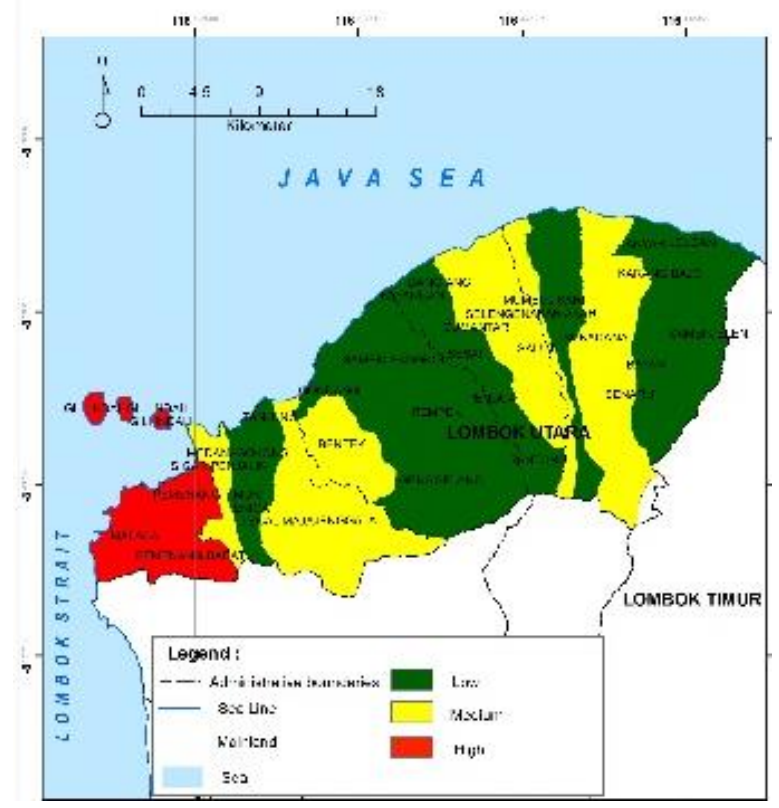

Fig. 3.2 Physical Capacity Map

According to the physical capacity map, the area of malaka village, pemenang barat, pemenang timur, and gili indah have high physical capacity. The area of sigar penjalin village, tegal, maja, bentek, gumantar, selengan, salut, mumbul sari, sukadana, and senaru have medium physical capacity. And the low one are teniga village, tanjung, tegal maja, medana, gondang genggalang, rempek, sambik bangkol, pendua, santong sesait, kayangan, dangiang, akar-akar, bayan, anyar, karang bajo, loloan, and sambik elen.

High physical capacity only $9.0 \%$ from the area of north lombok district, medium physical capacity are $39.50 \%$, and the low physical capacity are $51.50 \%$.

\subsection{Institutional Capacity}

Institutional capacity is a parameter related to the aid organizations. The aid organizations is the existence of organization such as community disaster management, and whether or not they exist of disaster risk reduction efforts.

Zoning area with the level of aid organization made by dividing 3 classes, that is villages that do not have disaster management institutions given score 1 , villages that have disaster management institutions but are not functioning given score 3 , and village that has institutional and functioning given score 5.

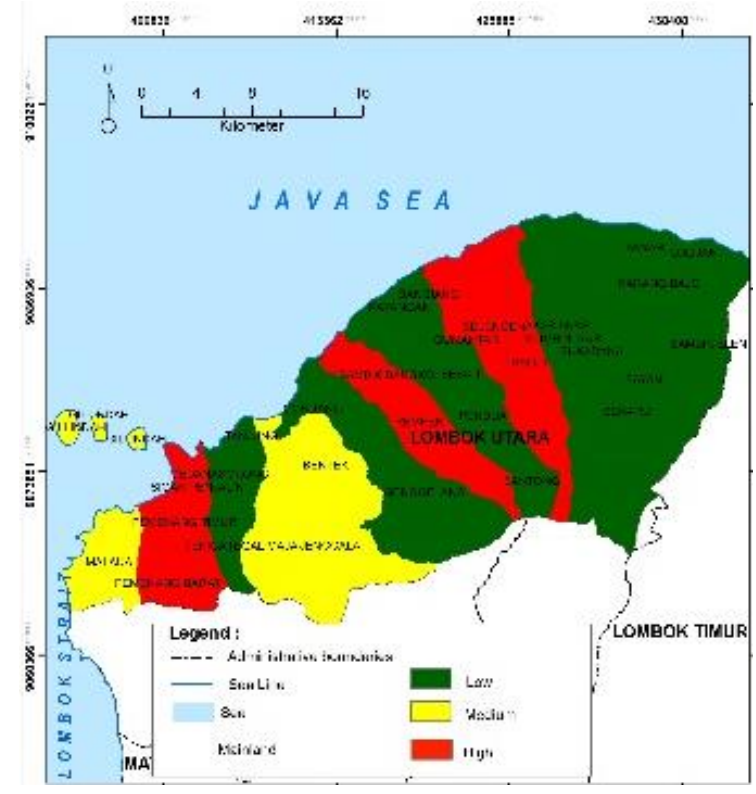

Fig. 3.3 Institutional Capacity Map

According to the institutional capacity map, the area that have high institutional capacity are pemenang barat village, pemenang timur, sigar penjalin, rempek, gumantar, salut, and mumbul sari. The area that have medium institutional capacity are malaka village, gili indah, tegal maja, jenggala, bentek. And the low one are teniga village, sokong, gondang, genggalang, sambik bangko, pendua, sesait, kayangan, dangiang, santong, anyar, akar-akar, bayan, karang bajo, loloan, sukadana, mumbul sari, senaru, and sambil elen.

The high institutional capacity are $24.22 \%$ from the area of the north lombok district, the medium institutional capacity are $19.18 \%$, and the low institutional capacity are $56.60 \%$.

\subsection{Capacity Map}

The earthquake Capacity map of the north lombok district used the overlay of the map from the parameters used. Every parameters scored by the level of influence in the forming of the earthquake capacity map. To determine the capacity level of each area, the capacity level divided into five level that is very high, high, medium, low, and very low. 


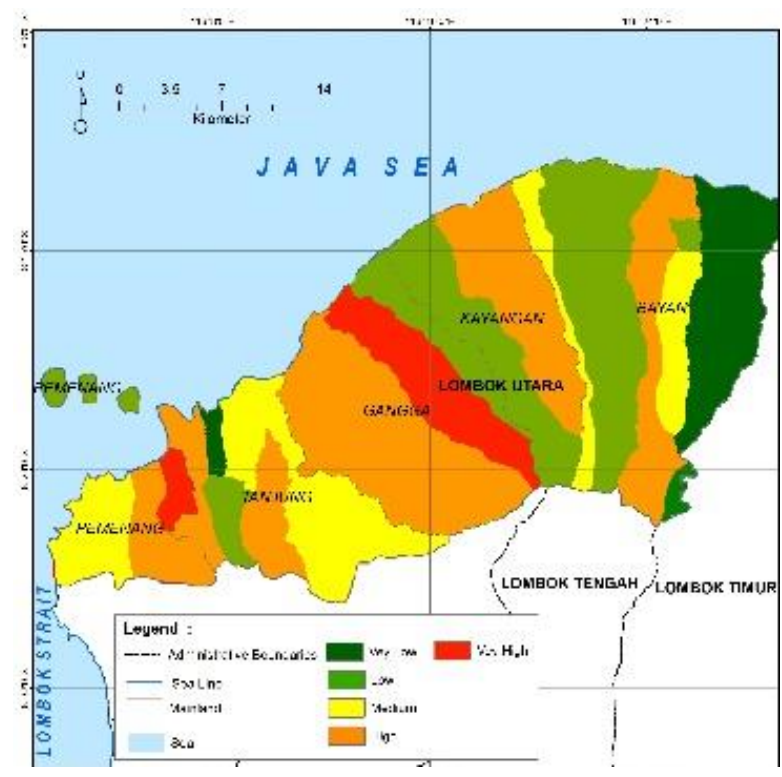

Fig. 3.4 Capacity Map

According to the capacity map, there are two areas that have very high capacity level that is pemenang timur village and rempek village. Area of high capacity level are pemenang barat village, sigar penjalin, tegal maja, bentek, gondang, genggalang, gumantar, selengan, salut, senaru, and anyar. The medium capacity area are malaka village, sokong, tanjung, jenggala, mumbul sari, and bayan. The low capacity are teniga village, gili indah, sambik bangkol, kayangan, dangiang, sesait, pendua, santong, akar-akar, sukadana, and karang bajo. And the lowest one are medana village, loloan, and sambik elen.

\section{Conclusion}

- To know the level of earthquake capacity in the northern Lombok region done by mapping with some parameters that is social capacity, physical capacity and institutional capacity.

- For social capacity parameter, people who do not understand about the disaster are $69.5 \%$ from the area of north lombok district, and the understand one are $30.5 \%$ from the area of north lombok district.

- For physical capacity parameter, high physical capacity only $9.0 \%$ from the area of north lombok district, medium physical capacity are $39.50 \%$, and the low physical capacity are $51.50 \%$.

- For institutional capacity parameter,The high institutional capacity are $24.22 \%$ from the area of the north lombok district, the medium institutional capacity are $19.18 \%$, and the low institutional capacity are $56.60 \%$.

\section{Reference}

1. Wiriasto, G.W., Misbahuddin., Akbar, L.S, I., Zubaidah, T. 2013. Tabulasi data dari seismograf analog Gn.Rinjani Tahun 1994-1998 sebagai tahap perancangan Sistem Informasi Monitoring Seismograf Online (SIMLine). Conference on SmartGreen Technology in Electrical and Information Systems. ISBN: 978-602-7776-72-2.

2. Kinasih, I.P., Wiriasto, G.W., Kanata, B., Zubaidah, T. 2014. Lesser Sunda Island Earthquake InterOccurrence Times Distribution Modeling. International Journal of Technology, Vol. 3: 242-250.

3. Agustawijaya, D.S., Syamsuddin. 2012. The Development Of Hazard Risk Analysis Method: A Case Study In Lombok. Dinamika Teknik Sipil/Vol.12/No.2/Mei 2012/.

4. Manfré, Luiz A., Eliane Hirata, Janaína B. Silva, Eduardo J. Shinohara, Mariana A. Giannotti, Ana Paula C. Larocca and José A. Quintanilha. 2012. An Analysis of Geospatial Technologies for Risk and Natural Disaster Management. ISPRS International Journal of Geo-Information. doi:10.3390/ijgi1020166.

5. Hashemi, Mahdi., Ali Asghar Alesheikh. 2011. A GIS-based earthquake damage assessment and settlement methodology. Soil Dynamics and Earthquake Engineering 31 (2011) 1607-1617.

6. Oettle, Nicolas K., Jonathan D. Bray, F.ASCE. 2013. Geotechnical Mitigation Strategies for Earthquake Surface Fault Rupture. American Society of Civil Engineers.DOI: $\quad 10.1061 /(A S C E) G T .1943-$ 5606.0000933 .

7. Heron, D., B. Lukovic, C. Massey, W. Ries and M. McSaveney. 2014.GIS modelling in support of earthquake-induced rockfall and cliff collapse risk assessment in the Port Hills, Christchurch. Journal of Spatial Science. Vol. 59, No. 2, 313-332, http://dx.doi.org/10.1080/14498596.2014.913509.

8. Costa, A. Campos., M. L. Sousa., A. Carvalho E. Coelho. 2009.Evaluation of seismic risk and mitigation strategies for the existing building stock: application of LNECloss to the metropolitan area of Lisbon. Bull Earthquake Eng (2010) 8:119-134. DOI 10.1007/s10518-009-9160-3 